\title{
IMPACT OF COMMERCIAL BANKS' CREDIT TO THE REAL SECTOR ON ECONOMIC GROWTH IN NIGERIA
}

\author{
Courage Ose Eburajolo, Leonard Nosa Aisien \\ Department of Economics, Banking and Finance, Faculty of Social and Management \\ Sciences, Benson Idahosa University, Benin City, Nigeria \\ cebebhahon@biu.edu.ng \\ laisien@biu.edu.ng
}

\begin{abstract}
The study examined the effect of commercial bank sectorial credit to the manufacturing and agricultural sub-sectors on economic growth in Nigeria with time series data from 1981 to 2015, using co-integration and error correction mechanism for the empirical work. A three equation model was specified to analyze this study, and the variables include; real GDP, bank sectorial credit to manufacturing and agriculture subsectors, monetary policy rate, financial market development, sourced from CBN statistical bulletin and also the interaction variables,. The variables were tested for unit root using the Augmented Dickey Fuller approach and were found to be stationary. The empirical result revealed that commercial bank credit to the manufacturing and agricultural subsectors significantly affects economic growth in Nigeria both in the short run and in the long run. Furthermore, development of the financial sector enhances the growth effects of commercial banks credit to the manufacturing and agricultural subsectors of the economy. It was therefore recommended that the Nigerian apex financial authorities should encourage banks via deliberate policy to increase credits to these subsectors of the economy.
\end{abstract}

Key words: financial development, real sector, economic growth, commercial banks credits, agricultural sector, manufacturing sector.

JEL classification: E44, Q14.

\section{Introduction}

Nigeria is an oil rich country with an estimated proven oil reserve of 35 billion barrels and 100 trillion cubic feet of natural gas. The country depends heavily on this oil sector for both foreign exchange and government revenue. Hence, shocks in the oil price influences activities in the economy greatly. With the recent glut in the global oil market coupled with the activities of the Niger delta militants, the country slid into a deep recession in 2015 . According to the National Bureau of Statistics (2016), the decrease in the growth rate of Nigeria has been as a result of fewer sectors experiencing rapid growth as well as the crude oil production seeing a decline.

On this basis, there has been a renewed call for the diversification of the productive base of the economy from crude oil. In this direction, the agricultural and manufacturing sub-sectors have come under focus. Undoubtedly, some attentions have been given to the manufacturing and agricultural sub-sectors in Nigeria by providing them with funds through various banking agents other than the deposit money banks in recent times. Among these agencies are the bank of industry (BOI), bank of agriculture, and the Nigeria Agricultural and Cooperative Bank (NACB).It is therefore appropriate to assume that high productivity in these sectors will translate into significant contributions to economic growth through the efforts of these agencies. However, research has shown that a number of small and medium

\footnotetext{
${ }^{*}$ Corresponding author: Dr. Leonard Nosa Aisien
} 
scale manufacturing firms and agriculturist in developing countries including Nigeria, are faced with the challenge of accessibility to bank credits which can be attributed to the underdeveloped structure of our financial system, as compared with their counterparts from other parts of the world with well-defined and developed financial structure (Loening, Rijkers, and Soderbom, 2008). Hence, one constraint identified in the literature hindering agricultural and manufacturing sub-sectors is poor access to bank credits. This goes further to show that there is a vital missing link between the financial sector and the real sector of the economy. In view of the importance of stimulating growth in the real sector, monetary authorities around the globe strive to focus on ensuring a sound, reliable and stable financial system which can impact on the real sector growth to a larger extent. Indeed, it is has been argued that a well-developed, dynamic, well-functioning, and vibrant financial sector will lead to improved economic outputs performance (Levine, 1997; Demirguc-Kunt and Levine, 2008). This observation and findings prompted this study which is aimed at investigating the impact of deposit money bank credit to the real sector economy in Nigeria. The study seek to ascertain if financial sector development (financial deepening) enhances the growth effect of bank credit to the real sector in the Nigerian economy. The study is therefore an empirical verification of the finance-growth theory as posited by Goldsmith 1969 using time series data from Nigeria.

The general hypothesis tested in the study is given as:

$\mathrm{H}_{0}$ : Financial sector development does not enhance the growth effect of commercial credit to the real sector in the Nigerian economy.

The study is structured into five sections. Apart from section one which deals with the introduction, section two covers the review of relevant literature. The theoretical framework and model specification are contained in section three, while the empirical results are resented in section four. The conclusion and policy recommendations are presented in section five.

\section{Review of literature}

Several empirical examinations have been done in the area commercial bank sectorial lending and economic growth. However, the studies came up with mixed results.

Fredrik, Katarzyna and Sonja (2016) using Granger Causality test, examined the performance of the different types of finance institutions' credit on the manufacturing sector output of china for the period between 1997 and 2008. The analysis revealed that the state owned banks and rural credit cooperatives has a negative effect on manufacturing sector growth and also does not granger cause growth in the sectors. Policy banks and joint stock commercial banks was found to promote growth.

Avinash and Mitchell-Ryan (2009) employed vector error correction modelling technique to investigate the impact of sectorial distribution of commercial bank lending on economic growth in Trinidad and Tobago. They noticed that deposit money banks' credit play a significant role in the way households and corporate firms finance economic transactions. From their result it was revealed that there is a supply leading relationship between credit and growth within key sectors of the nonoil economy.

In Nigeria, several studies have been done on sectorial allocation of commercial banks credits and its impact on economic growth. Some of the studies including Adeyinka, Daniel and Olukotun (2015), Ogar, Nkamare and Effiong (2014), Ebi and Nathan (2014), Ebele and lorember (2016), Toby and Peterside (2014), Bada (2017), Uzomba, Chukwu, Jumbo and Nwankwo (2014), and Hassan (2016), found a positive and significant relationship between commercial bank to various sectors and economic growth in Nigeria for deferent time periods. The studies of Obilor (2013), Yakubu and Affoi (2014) and Anyiwe (2003) examined the impact of commercial banks credits (in aggregate terms) on economic growth in Nigeria. 
They also found a positive and significant relationship between commercial bank credits and economic growth in Nigeria.

However, the study of Sogules and Nkoro (2016) which analyzed the influence of bank credits to agricultural and manufacturing sectors on economic growth in Nigeria for period of 1970 to 2013 found a negative relationship. While the impact of credit to agriculture was insignificant even at $10 \%$, the impact of credit to the manufacturing sector on economic growth was significant. Similarly, the study of Imoughele and Ismaila (2013) on the impact of commercial bank credits to agricultural on economic growth in Nigeria revealed that the impact of credit to agricultural sector is statistically insignificant in Nigeria in the short run.

From the above review, it shows that there is no consensus on the impact of commercial banks credit to the real sector on economic growth. Moreover, none of the studies considered the role of financial deepening (financial sector development) in enhancing the economic growth potential of commercial banks credit to the real sector of the economy. This is the area this study seek to address.

\section{Theoretical framework and model specification}

\subsection{Theoretical framework}

The study relied seriously on the finance-growth theory for its theoretical underpinning of the link between the financial sector and the real sector. The finance-growth theory is built on the traditional financial intermediation function of banks which enables banks to intermediate not only between the surplus and deficits units, but also between the financial sector and the real sector of the economy. The finance-growth relationship motivated the novel research of Goldsmith (1969) to validate the exact influence of finance on economic growth so as to improve upon the traditional banking theory that fosters the relationship between the various sectors in the economy.

This theory asserts a direct relationship between the financial sector and the real sector through the size of the financial sector. That is, as the financial system becomes more developed in terms of size and scope of activities, its contributions to economic growth increases through the provision of sophisticated debt instruments which enhances financing. The financial intermediation and growth theory rest on three pillars, known as the transformation mechanism which is determined by interest rate and the intermediation ability of deposit money banks. They are size transformation mechanism, maturity transformation mechanism, and Risk transformation mechanism.

According to Dewatripont, Rochet and Tirole (2010), these transformation mechanisms are basically the banks' ability to annex savings, pool it, and aggregate loans to the deficit sector; create liquidity by borrowing short and lending long; and also reducing both the cost of information and transaction cost, (finance collection, and investment sourcing), hence limiting the risk faced by individual creditors.

\subsection{Model specification}

The model is a modification of Goldsmith (1969) finance-growth model. According to the model as explained in the theoretical framework above, economic growth is a function of bank credit to the real sector. Also, the growth benefits of the credit to the real sector is enhanced by the development of the financial sector. In this study, the real sector is captured by agriculture and manufacturing sectors. The role of the financial sector development is examined using the interaction variable technique. The econometric form of the models for estimation are given as:

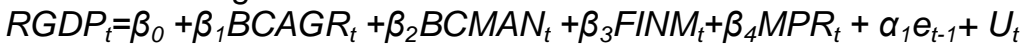


$R G D P_{t}=\beta_{0}+\beta_{1} B C A G R_{t}+\beta_{2} B C M A N_{t}+\beta_{3}$ FINM $_{t}+\beta_{4}$ MPR $_{t}+\beta_{5}\left(B C A G R^{*} F I N M\right)_{t}+\alpha_{1} e_{t-1}+U_{t}$ (2) $R G D P_{t}=\beta_{0}+\beta_{1} B C A G R_{t}+\beta_{2} B C M A N_{t}+\beta_{3}$ FINM $_{t}+\beta_{4}$ MPR $_{t}+\beta_{5}\left(B C M A N^{*} F I N M\right)_{t}+\alpha_{1} e_{t-1}+U_{t}$ (3) Where;

RGDP = Real Gross Domestic Product of Nigeria (Proxy for economic growth)

BCAGR $=$ Total Commercial Bank Credit to Agricultural sector in Nigeria.

BCMAN = Total Commercial Banks Credit to Manufacturing Sector in Nigeria.

FINM = Ratio of M2 to RGDP (Proxy for Financial Development)

MPR = Monetary Policy Rate of the Central Bank of Nigeria

$(B C A G R)^{\star}(F I N M)=$ Interaction Variable for Agricultural Sector and Financial Development $(B C M A N) *(F I N M)=$ Interaction Variable for Manufacturing Sector and Financial Development The study employed the co-integration and error correction modeling technique to estimate the short run and long coefficients of the variables.

\section{Presentation and Interpretation of Empirical Results}

\subsection{Unit Root Test:}

The Augmented Dickey Fuller (ADF) test was adopted to test for stationarity. The result is presented in the table below:

Table 2: Unit Root Test of Variables

\begin{tabular}{|c|c|c|c|}
\hline Variables & ADF Test Statistic & $\begin{array}{l}\text { ADF Critical } \\
\text { Values ( } 5 \% \text { level) }\end{array}$ & Remark \\
\hline RGDP & 1.2545 & 2.9540 & Non - stationary \\
\hline DRGDP & 3.1102 & 2.9540 & Stationary \\
\hline BCMAN & 1.2861 & 2.9810 & Non - stationary \\
\hline DBCMAN & 3.5477 & 2.986 & Stationary \\
\hline BCAGR & 3.7633 & 2.9762 & Stationary \\
\hline FINM & 3.5894 & 2.9511 & Stationary \\
\hline MPR & 3.0346 & 2.9511 & Stationary \\
\hline
\end{tabular}

From the above result, financial development, monetary policy rate and commercial banks credit to agricultural sub-sector were integrated of order zero, while real GDP, and commercial banks credit to the manufacturing sector were integrated of order one.

The above results implies that not all the variables are stationary at levels. Regressing non stationary variables may lead to spurious regression. However, non-stationary can only be regressed if they are co-integrated. Hence, the next step of the analysis is to test for co-integration.

\subsection{Co-Integration Test}

In order to test for co-integration among the variables, the Johansen Co-integration test was used. The test was based on trace statistics at $5 \%$ level. The result is presented in the table below:

Table 3: Johansen Co-integration Test

\begin{tabular}{|l|c|c|c|c|}
\hline $\begin{array}{l}\text { Hypothesized No. of } \\
\text { co-integrating equations }\end{array}$ & Eigenvalue & $\begin{array}{l}\text { Trace } \\
\text { Statistics }\end{array}$ & $\begin{array}{l}\text { Critical value } \\
\text { at 5\% level }\end{array}$ & Probability \\
\hline None $^{*}$ & 0.876 & 122.488 & 69.818 & 0.000 \\
At most 1* & 0.505 & 53.551 & 47.856 & 0.013 \\
At most 2* & 0.448 & 30.309 & 29.797 & 0.043 \\
At most 3 & 0.275 & 10.669 & 15.494 & 0.230 \\
At most 4 & 0.002 & 0.078 & 3.8414 & 0.779 \\
\hline
\end{tabular}

${ }^{*}$ denote rejection of the hypothesis at 0.05 level 
Oradea Journal of Business and Economics, Volume IV, Issue 1

Published on March 2019

From the trace statistics in the above table, compared with its critical value at $5 \%$, three co-integrating equations can be observed. This implies that the variables are co-integrated.

\subsection{Short Run Error Correction Representation}

Since the variables are co-integrated, it is safe to estimate the specified model. In order to examine the dynamic stability of the model the error correction representation model was estimated. The error correction representation was conducted based on the R-Bar squared criterion. In this case the lagged is selected automatically and redundant lagged values are omitted from the final parsimonious estimates. The error correction result is presented in the table below:

Table 4: Error Correction Representation

\begin{tabular}{|c|c|c|c|}
\hline Variables & Equation 1 & Equation 2 & Equation 3 \\
\hline dRGDP(1) & $\begin{array}{l}0.631^{*} \\
(3.222)\end{array}$ & - & - \\
\hline dBCAGR & $\begin{array}{c}12.815^{\star \star \star} \\
(1.748)\end{array}$ & $\begin{array}{l}1.012^{*} \\
(3.411)\end{array}$ & $\begin{array}{l}2.384^{* *} \\
(2.372)\end{array}$ \\
\hline $\mathrm{dBCAGR}(1)$ & ( & 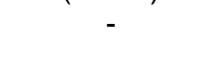 & $\begin{array}{l}1.030^{\star \star *} \\
(2.972)\end{array}$ \\
\hline dBCAGR(2) & - & - & $\begin{array}{l}6.501^{* *} \\
(2.208)\end{array}$ \\
\hline dBCMAN & $\begin{array}{c}3.533^{* * *} \\
(1725)\end{array}$ & $\begin{array}{c}1.295^{\star} \\
(11953)\end{array}$ & $\begin{array}{l}2.851^{* *} \\
(2380)\end{array}$ \\
\hline $\mathrm{dBCMAN}(1)$ & $\begin{array}{l}3.278^{\star *} \\
(2.536)\end{array}$ & $\begin{array}{l}6.258^{*} \\
(3.047)\end{array}$ & $\begin{array}{c}1.580 \\
(0.600)\end{array}$ \\
\hline dBCMAN(2) & $\begin{array}{l}3.278^{*} \\
(2.869)\end{array}$ & $\begin{array}{l}1.005^{*} \\
(2.964)\end{array}$ & $\begin{array}{l}5.459^{* *} \\
(2.744)\end{array}$ \\
\hline dFINM & $\begin{array}{l}8.987^{* *} \\
(2.118)\end{array}$ & $\begin{array}{l}4.158 \\
(0.776)\end{array}$ & $\begin{array}{l}2.900 \\
(0.556)\end{array}$ \\
\hline $\mathrm{dFINM}(1)$ & $\begin{array}{l}1.940^{* * *} \\
(1.931)\end{array}$ & $\begin{array}{l}5.531^{*} \\
(3.150)\end{array}$ & $\begin{array}{l}3.176^{\star *} \\
(2.243)\end{array}$ \\
\hline $\mathrm{dFINM(2)}$ & $\begin{array}{l}2.152^{* *} \\
(2301)\end{array}$ & $6.816^{*}$ & $3.837^{* *}$ \\
\hline dMPR & 17.464 & -8.340 & 26.631 \\
\hline & $(0.461)$ & $(-0.206)$ & $(0.769)$ \\
\hline dMPR(1) & - & - & $\begin{array}{l}45.964 \\
(1.217)\end{array}$ \\
\hline $\mathrm{d}(\mathrm{BCAGR})^{\star}(\mathrm{FINM})$ & - & $\begin{array}{c}3.956 \\
(1.307)\end{array}$ & 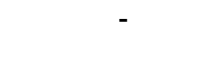 \\
\hline $\mathrm{d}(\mathrm{BCAGR})^{\star}(\mathrm{FINM})(1)$ & - & $\begin{array}{l}2.328^{* \star} \\
(2.685)\end{array}$ & - \\
\hline $\mathrm{d}(\mathrm{BCAGR})^{*}(\mathrm{FINM})(2)$ & - & $\begin{array}{l}1.723^{\star *} \\
(2.585)\end{array}$ & - \\
\hline $\mathrm{d}(\mathrm{BCMAN})^{\star}(\mathrm{FINM})$ & - & - & $\begin{array}{c}9.7510^{* *} \\
(2.225)\end{array}$ \\
\hline $\mathrm{d}(\mathrm{BCMAN})^{*}(\mathrm{FINM})(1)$ & - & - & $\begin{array}{l}2.921^{* *} \\
(2.437)\end{array}$ \\
\hline$d C$ & $\begin{array}{l}2573.3 \\
(1.641)\end{array}$ & $\begin{array}{l}1245.6 \\
(0.854)\end{array}$ & $\begin{array}{l}2746.1 \\
(2.120)\end{array}$ \\
\hline $\operatorname{ECM}(-1)$ & $\begin{array}{c}-0.175^{\star \star *} \\
(-1.769)\end{array}$ & $\begin{array}{c}-0.108^{\star \star \star} \\
(-2.110)\end{array}$ & $\begin{array}{l}-0.281^{\star * *} \\
(-2.884)\end{array}$ \\
\hline $\begin{array}{l}\text { R-SQUARED } \\
\text { F-STATISTICS } \\
\text { DW - STATISTICS } \\
\text { DEPENDENTVARRIABLE } \\
\mathrm{N}\end{array}$ & $\begin{array}{c}0.878 \\
13.016[0.000] \\
2.439 \\
\text { RGDPG } \\
32 \\
\end{array}$ & $\begin{array}{c}0.910 \\
11.805[0.000 \\
1.978 \\
\text { RGDPG } \\
32 \\
\end{array}$ & $\begin{array}{c}0.946 \\
15.034[0.000] \\
2.222 \\
\text { RGDPG } \\
32 \\
\end{array}$ \\
\hline
\end{tabular}


${ }^{*}$ significant at $1 \%{ }^{* *}$ significant at $5 \%{ }^{* * *}$ significant at $10 \%$

In the result above, Column 1, shows short run estimates of the specified model with the interaction variables. In Column 2, interaction variable of Commercial Banks Credit to the agricultural sub-sector and financial development was introduced. In Column 3, Commercial Banks credit to the manufacturing sub-sector and financial development was introduced. In all the estimates, the error correction terms (ECM) were properly signed with a coefficient of $-0.175,-0.108$ and -0.281 for column 1,2 and 3 respectively. Also, they were all statistically significant. This shows that the model is dynamically stable.

\subsection{Long run coefficients of variables}

The corresponding long run coefficients are presented in the table 5 below:

Table 5: The Long Run Coefficients of Variable

\begin{tabular}{|c|c|c|c|}
\hline Coefficient & Equation 1 & Equation 2 & Equation 3 \\
\hline BCAGR & $4.204^{*}$ & $\begin{array}{l}7.910^{*} \\
7277\end{array}$ & $2.747^{\star \star *}$ \\
\hline & (3.285) & (2.737) & (2.118) \\
\hline BCMAN & $2.157^{* *}$ & $7.930^{*}$ & $8.204^{* *}$ \\
\hline & (2.192) & $(2.487)$ & $(2.130)$ \\
\hline FINM & $1.284^{* *}$ & $5.985^{\star}$ & $1.384^{* *}$ \\
\hline & $(2.460)$ & (2.974) & $(2.317)$ \\
\hline MPR & $99.249^{*}$ & $3.805^{*}$ & $5.051^{* *}$ \\
\hline$(\mathrm{BCAGR})^{*}(\mathrm{FINM})$ & $\begin{array}{c}(4.616) \\
-\end{array}$ & $\begin{array}{l}(2.370) \\
1.363^{*}\end{array}$ & $\begin{array}{c}(3.149) \\
-\end{array}$ \\
\hline & & (10.907) & \\
\hline$(\mathrm{BCMA})^{*}(\mathrm{FINM})$ & - & - & $5.915^{*}$ \\
\hline & & & (3.149) \\
\hline C & $14623.9^{*}$ & 11462 & $9744.4^{*}$ \\
\hline & $(4.161)$ & $(1.724)$ & $(4.132)$ \\
\hline
\end{tabular}

${ }^{*}$ sig at $1 \%{ }^{* *} \operatorname{sig}$ at $5 \%{ }^{* * *} \operatorname{sig}$ at $10 \%$

The estimated long run coefficients of the selected variables using the autoregressive distributed lagged approach based on $r$-bar square is presented in the table above. In column 1 the growth model without interaction variable was estimated. In column 2 the interaction variable was introduced, in this column the interaction of credit to agricultural with financial development was introduced. In column three, the variable to capture the interaction between credit to manufacturing sector and financial development was introduced. All the variables including the interaction variables had positive sign and their impact were statistically significant.

\subsection{Policy Implications of Findings}

Following the results above these are some of the implications of the findings:

i. Commercial bank credit to the agricultural sector has a positive and significant impact on economic growth in Nigeria both in the short run and in the long run. Hence the more credit the commercial banks grant to the agricultural sector, the more vibrant the economy will become.

ii. Commercial bank credit to manufacturing sector has a positive and significant impact on economic growth in Nigeria both in the short and the long run. Hence, the more credit commercial bank grant to the manufacturing sector the more rapid the economy will accelerate. 
iii. The impact of monetary policy rate on economic growth is not statistically significant in the short run but highly significant in the long run. This shows that the relationship between monetary policies and economic growth is long run phenomenon.

iv. Development of the financial sector has a positive and significant impact on economic growth in Nigeria both in the short run and in the long run.

v. The growth potentials of the credit allocated to the agricultural sector and the manufacturing sector by commercial banks is greatly enhanced by development of the financial system of the economy.

Flowing from the above, the null hypothesis which state that financial sector development does not enhance the growth effect of commercial banks credit to the real sector in Nigeria is rejected while the alternative hypothesis is accepted.

\section{Policy Recommendation and Conclusion}

\subsection{Policy Recommendation}

In the light of the analysis and findings, this study therefore validated the hypothesis which state that financial sector development enhances the growth effect of commercial banks credit to the real sector in the Nigerian economy. The following recommendations are therefore considered necessary for short and long term implementations. They are:

1. The Nigerian apex financial authorities CBN, should encourage bank credits to these two sectors (agriculture and manufacturing) because it has incentives of boosting economic growth both in short and long run. Thus the more credit channeled to these sectors through government policies, the more vibrant the economy will become.

2. Also very important, is the impact of monetary policy rate (MPR) on economic growth, which was found to be significant in the long run. This shows that MPR has a delayed effect on savings and investment which may affect banks' ability to grant credits. CBN should put in place other measures that can respond quicker to get the desired result.

3 . It is also worthy to note the key role of a well-developed financial system and its supplementary role to bank credit to the manufacturing and agricultural sub sectors. Development of the financial sector has a positive and significant impact on economic growth in Nigeria both in the short run and in the long run. Government should as a matter of deliberate policy ensure a well-developed financial system. This is because growth potentials of the credit allocated to the agricultural sector and the manufacturing sector by commercial banks is greatly enhanced by development of the financial system of the economy.

\subsection{Conclusion}

This study investigated the impact of commercial banks' credit to the real sector on economic growth in Nigeria with a major focus on the agricultural and manufacturing subsectors during the period 1981-2015, using data from the CBN bulletin. Following the objectives of the study, real GDP was estimated as a function of, bank credits to the subsectors, financial development (ratio of broad money supply to GDP), monetary policy rates, and the interaction variable (product of bank credit to subsectors and financial development). The empirical results confirmed the existence of both short run and long run effects of the aforementioned variables on real GDP except for MPR with only long run effects. This is an indication that the variables are consistent and hence robust.

The study therefore revealed that financial development has played a significant role in economic growth in Nigeria during the period covered by the study. The findings therefore, validate the hypothesis which states that financial sector development enhances the growth effect of commercial banks credit to the real sector of the Nigerian economy. The implication 
of this is that government should be proactive and devise means to boost the Nigerian financial system so as to be able to attract not only local investments, but also foreign financial investments.

\section{References:}

Adeyinka, A.J., Daniel, A.A., and Olukotun, G.A., 2015. An assessment of the contribution of commercial banks to agriculture financing in the Nigerian economy. International Journal of Advanced Academic Research-Social Science and Education, 1(2) pp. 23-45

Anyiwe, M. A. 2003., Commercial bank credit and economic growth in Nigeria, 1970 - 1996. Finance India, 17(3), pp. 4239-4245

Avinash, R., and Mitchell-Ryan, T., 2009. An assessment of the impact of the sectorial distribution of commercial bank credit on economic growth and development in Trinidad and Tobago. Central Bank of Trinidad and Tobago. CBB Working Paper, 2010.

Bada, O. T., 2017. The effect of banks' credits on the development of Manufacturing and agricultural sectors of Nigeria's economy. International Journal of Advanced Studies in Economics and Public Sector Management. 5(1), pp 114-130

Demirguc-Kunt, A. and Levine R., 2008. Finance, financial sector policies and long- run growth. World Bank Policy Research Working Paper, No 4469

Dewatripont, M., Rochet, J.-C., and Tirole, J., 2010. Balancing the banks: Global lessons from the financial crisis. Princeton University Press, Princeton

Ebele, E. J., and lorember, P. T., 2016. Commercial bank credit and manufacturing sector output in Nigeria. Journal of Economics and Sustainable Development 7(16), pp. 189-196.

Ebi, B.O., and Nathan, E., 2014. Commercial bank credits and industrial subsector's growth in Nigeria. Journal of economics and sustainable Development 5(9), pp14-27.

Fredrik, N. G., Katarzyna, B., and Sonja O., 2016. Lending for growth? A Granger causality analysis of China's finance-growth nexus. Empirical. Economics 51, pp. 897-920.

Goldsmith, R. W., 1969. Financial structure and development, New Haven, CT: Yale University Press.

Hassan O. M., 2016. Implications of commercial bank loans on economic growth in Nigeria (1986-2014). Journal of Emerging Trends in Economics and Management Sciences 7(3), pp.124-136.

Imoughele, L. E., and Ismaila, M., 2013. Commercial bank credit accessibility and sectorial output performance in a deregulated financial market economy: Empirical evidence from Nigeria. Journal of Finance and Bank Management, 1(2), pp. 36-59.

Levine, R., 1997. Financial development and economic growth: Views and agenda. Journal of Economic Literature, 35, pp. 688-726.

Loening, J., Rijkers, B. and Soderbom, M., 2008. Non-farm microenterprise performance and the investment climate: Evidence from rural Ethiopia. World Bank, Policy Research Working Paper, No. 4577.

National Bureau of Statistics, 2016. The Nigerian Economy: Past, Present and Future. The Nigerian economic outlook 2016. www.nigerianstat.gov.ng [accessed July 28, 2017]

Obsilor, S.I., 2013. The impact of commercial banks' credit to agriculture on agricultural development in Nigeria: An econometric analysis. International Journal of Business, Humanities and Technology 3(1), pp. 85 -95.

Ogar, A., Nkamane, S. E., and Effiong, C., 2014. Commercial bank credit and its contributions on manufacturing sector in Nigeria. Research Journal of Finance and Accounting 5(22), pp. 188-196.

Sogules, I. W., and Nkoro, E., 2016. The impact of Bank credits to agricultural and manufacturing sectors on economic Growth in Nigeria. International Journal of Economics and Financial Research, 2 (4), pp. 74-78. 
Toby, A. J., and Peterside, D. B., 2014. Analysis of the role of banks in financing the agriculture and manufacturing sectors in Nigeria. International Journal of Research in Business Management, 2(2), pp. 9-22.

Uzomba, P. C., Chukwu, S. N., Jumbo, G. A. and Nwankwo, N. U., 2014. An inquiring into the impact of deposit money banks' loans and advances on agricultural sector in Nigeria; 1980-2011. International Review of Social Sciences and Humanities, 7 (2), pp. 130-139.

Yakubu, Z. and Affoi, A.Y., 2014. An analysis of commercial banks' credit on economic growth in Nigeria. Current Research Journal of Economic Theory. 6(2), pp. 11-15

\section{Bio-note}

Courage Ose Eburajolo (Mrs.) is a lecturer in the Department of Economics, Banking and Finance, Faculty of Social and Management Sciences, Benson Idahosa University, Benin City, Nigeria. She is currently a Ph.D. student of Finance at the University of Benin, Nigeria. Leonard Nosa Aisien, Ph.D is a senior lecturer and currently the head of Department of Economics, Banking and Finance, Faculty of Social and Management Sciences, Benson Idahosa University, Benin City, Nigeria. As a postdoctoral researcher, Aisien is focused on sources of economic growth in Sub-Saharian Africa, conducting studies on country specific and panel of sub-Sahara Africa countries. 